\title{
Begonia oyuniae (Begonia sect. Monophyllon, Begoniaceae), a remarkable new species from Northeast India
}

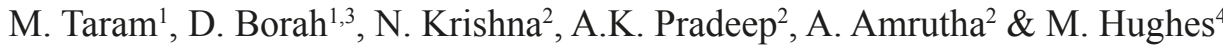 \\ ${ }^{1}$ Department of Botany, Rajiv Gandhi University, Rono Hills, \\ Doimukh 791112, Arunachal Pradesh, India \\ dipankar.borah@rgu.ac.in \\ ${ }^{2}$ Department of Botany, University of Calicut, Malappuram, Kerala 673635, India \\ ${ }^{3}$ Department of Botany, Goalpara College, Goalpara 783101, Assam, India \\ ${ }^{4}$ Royal Botanic Garden Edinburgh, 20A Inverleith Row, \\ Edinburgh EH3 5LR, Scotland, U.K.
}

\begin{abstract}
The new species Begonia oyuniae M.Taram \& N.Krishna is described from Arunachal Pradesh. It belongs to Begonia sect. Monophyllon A.DC., which is a new sectional record for India. Begonia oyuniae shares the ability to produce plantlets at the leaf tip with B. vagans Craib (Begonia sect. Alicida C.B.Clarke) and B. elisabethae Kiew (Begonia sect. Parvibegonia A.DC.), but differs from the former in having glabrous tepals (versus densely glandular hairy) and 2-locular ovaries (versus 3-locular), and from the latter in having an asymmetric androecium (not globose). It differs from the two other species in Begonia sect. Monophyllon in having leaves which have sinuate to lobed margins (not entire), and which produce plantlets around the margin.
\end{abstract}

Keywords. Begonia paleacea, Begonia prolifera, Begonia sect. Parvibegonia, Namdapha National Park, Sikem, taxonomy

\section{Introduction}

Begonia is among the largest angiosperm genera at 1962 accepted species (Hughes et al., 2015-). It is well-known for its horticultural potential with many species under cultivation for their ornamental value. The Begonia flora of Northeast India has hitherto been represented by a total of 38 species in the sections Begonia sect. Diploclinium (Lindl.) A.DC., sect. Parvibegonia A.DC., and sect. Platycentrum (Klotzsch) A.DC. (Camfield \& Hughes, 2018). During ongoing ethnobotanical studies in the moist subtropical forests of the Upper Siang district of Arunachal Pradesh, the first two authors collected an interesting specimen of Begonia. On critical evaluation of the specimens in different herbaria (CAL, ASSAM, K, E, PE) and relevant literature (Clarke, 1879; Gu et al., 2007; Camfield \& Hughes, 2018) it was found to be an undescribed species. Independently, the next three authors came across another population of the same species in Namdapha National Park in Arunachal Pradesh. The new species belongs in Begonia sect. Monophyllon A.DC., which until now comprised only two species (Begonia paleacea Kurz and Begonia prolifera A.DC.) distributed 
in Myanmar and Thailand (Doorenbos et al., 1998; Moonlight et al., 2018; Hughes et al., 2015-). The section is well defined morphologically, with species having 1 or 2 leaves and the inflorescence arising from the base of the leaf blade or slightly below on the petiole. The section is further defined by the following combination of characters: tuberous habit, pistillate flowers with two styles, two-locular fruit with three strongly unequal wings, and bifid placentae. These characters are also shared by Begonia sect. Parvibegonia A.DC, with which Begonia sect. Monophyllon is likely closely allied. However, species included in Begonia sect. Monophyllon are unique in the position of their inflorescence and the type of the section (B. prolifera) has an asymmetric androecium, not globose as in Begonia sect. Parvibegonia.

\section{Taxonomy}

\section{Begonia oyuniae M.Taram \& N.Krishna, sp. nov. § Monophyllon}

Begonia oyuniae belongs in Begonia sect. Monophyllon as it is a small tuberous herb with two lunate stigmas, two-locular fruit and an asymmetric androecium. Begonia oyuniae shares the ability to produce plantlets at the leaf tip with B. vagans Craib (Begonia sect. Alicida C.B.Clarke) and B. elisabethae Kiew (Begonia sect. Parvibegonia), but differs from the former in having glabrous tepals (versus densely glandular hairy) and 2-locular ovaries (versus 3-locular), and from the latter in having an asymmetric androecium (not globose). It differs from the two other species in Begonia sect. Monophyllon in having leaves which are sinuate to lobed (not entire), and which produce plantlets around the margin. - TYPE: INDIA, Arunachal Pradesh, Upper Siang district, Sikem, 28 21'39"N 954'17"E, 300 m, 22 May 2019, M. Taram 301 (holotype CAL; isotype ASSAM). (Fig 1-3).

Monoecious tuberous herb. Tubers globose to sub globose, $0.5-1 \mathrm{~cm}$ across, with numerous fibrous roots. Stem $2-15 \mathrm{~cm}$, internodes $2.3-5 \mathrm{~cm}$ long if present, glabrous. Stipules paired, axillary, opposite, ovate triangular, transparent with pale green stripes, minute (c. $1 \times 0.5 \mathrm{~mm}$; Krishna 159649$)$ or larger $(6-9 \mathrm{~mm} \times 4-6 \mathrm{~mm}$; Taram 301), membranous, glabrous, entire, acute. Leaves 1-2(-3); petiole channelled above, transparent, greenish white, $3-15 \mathrm{~cm} \times 2-6 \mathrm{~mm}$, glabrous; leaf lamina ovate-lanceolate, base cordate, symmetric to subsymmetric, margin obtuse-sinuate to acutely lobed, (6) $7(-8)$ palmate, $7-16.5 \times 3.5-14.5 \mathrm{~cm}$, membranous, succulent, adaxially light green, with irregularly dispersed stiff membranous hairs up to $1 \mathrm{~mm}$ long, abaxially whitish green, glabrous; venation palmate, c. 3 primary veins on each side; secondary veins pinnate; margin entire between the lobes, plantlets sometimes forming at the end of the lamina lobes, apex acute to shortly acuminate. Inflorescences arising from the petiole, bisexual, 4-19 cm long, whitish green, glabrous or with minute glandular hairs becoming glabrous, peduncle $2.5-11 \mathrm{~cm}$ long, branched up to 4 times, a raceme of cymes, erect. Bracts 2 (rarely 3), opposite, pale green, transparent, deciduous, lateral ones triangular-ovate to lanceolate, $3 \times 1-2 \mathrm{~mm}$, middle one (if present) linear, $0.5 \times 2 \mathrm{~mm}$, glabrous or minute glandular hairy when young, glabrous when mature, 


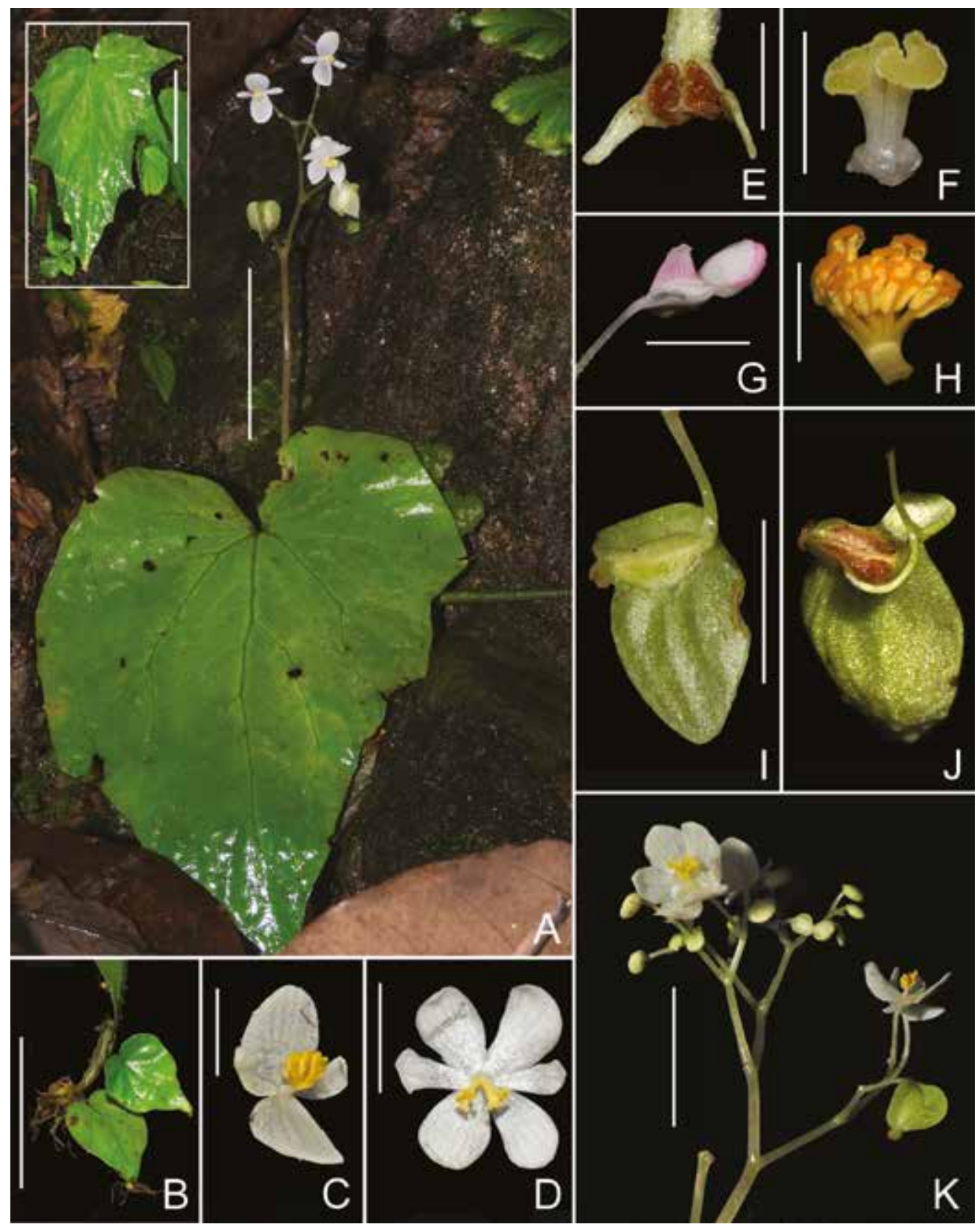

Fig. 1. Begonia oyuniae M.Taram \& N.Krishna. A. Habit in situ (inset showing a leaf with more pronounced lobes) (scale bars $5 \mathrm{~cm}$ ). B. Leaf tip with bulbils and plantlets, each with further bulbils (scale bar $1 \mathrm{~cm}$ ). C. Staminate flower (scale bar $1 \mathrm{~cm}$ ). D. Pistillate flower (scale bar $1 \mathrm{~cm}$ ). E. Fruit cross section showing two locules and two placental lamellae per locule (scale bar $5 \mathrm{~mm}$ ). F. Style and stigma (scale bar $2 \mathrm{~mm}$ ). G. Ovary and flower bud (scale bar 1 $\mathrm{cm}$ ). H. Androecium (scale bar $5 \mathrm{~mm}$ ). I. Ovary with one smaller wing removed (scale bar 1 $\mathrm{cm}$ ). J. Ovary with ripe seeds visible through the membraneous flaps in the splash cup (scale bar $1 \mathrm{~cm}$ ). K. Inflorescence (scale bar $3 \mathrm{~cm}$ ). A-D, I \& K from M. Taram 301; E-H \& J from N. Krishna 159649. (Photos: A-D, I \& K,.M. Taram; E-H \& J, N. Krishna) 


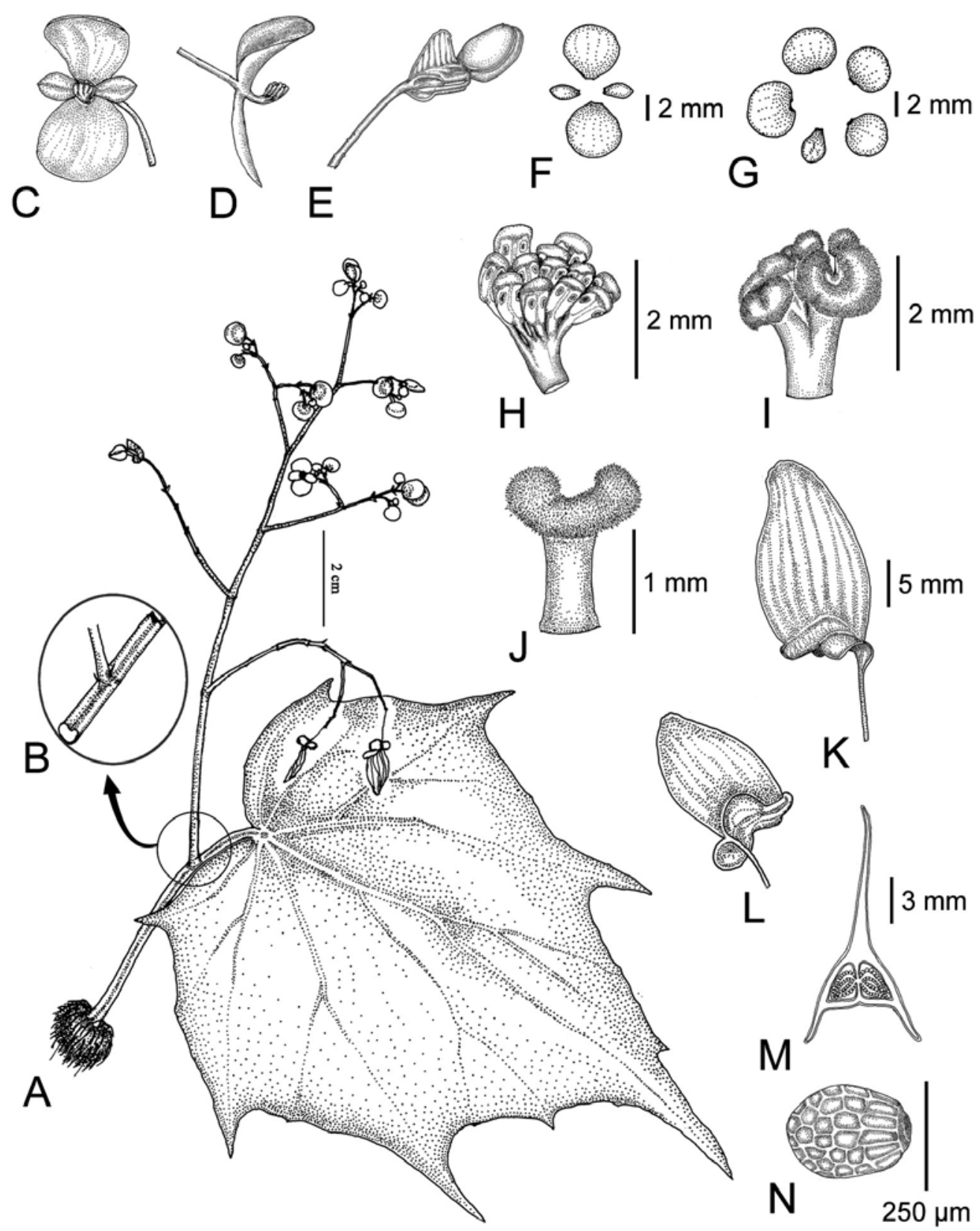

Fig. 2. Begonia oyuniae M.Taram \& N.Krishna. A. Habit. B. A closer view of peduncle attachment. C \& D. Staminate flower. E. Ovary and pistillate flower bud. F. Tepals of staminate flower. G. Tepals of pistillate flower. H. Androecium. I. Styles and stigmas. J. A single stylar branch. K \& L. Fruit. M. Ovary transverse section. N. Seed. Drawn by N. Krishna. All from N. Krishna 159649. 


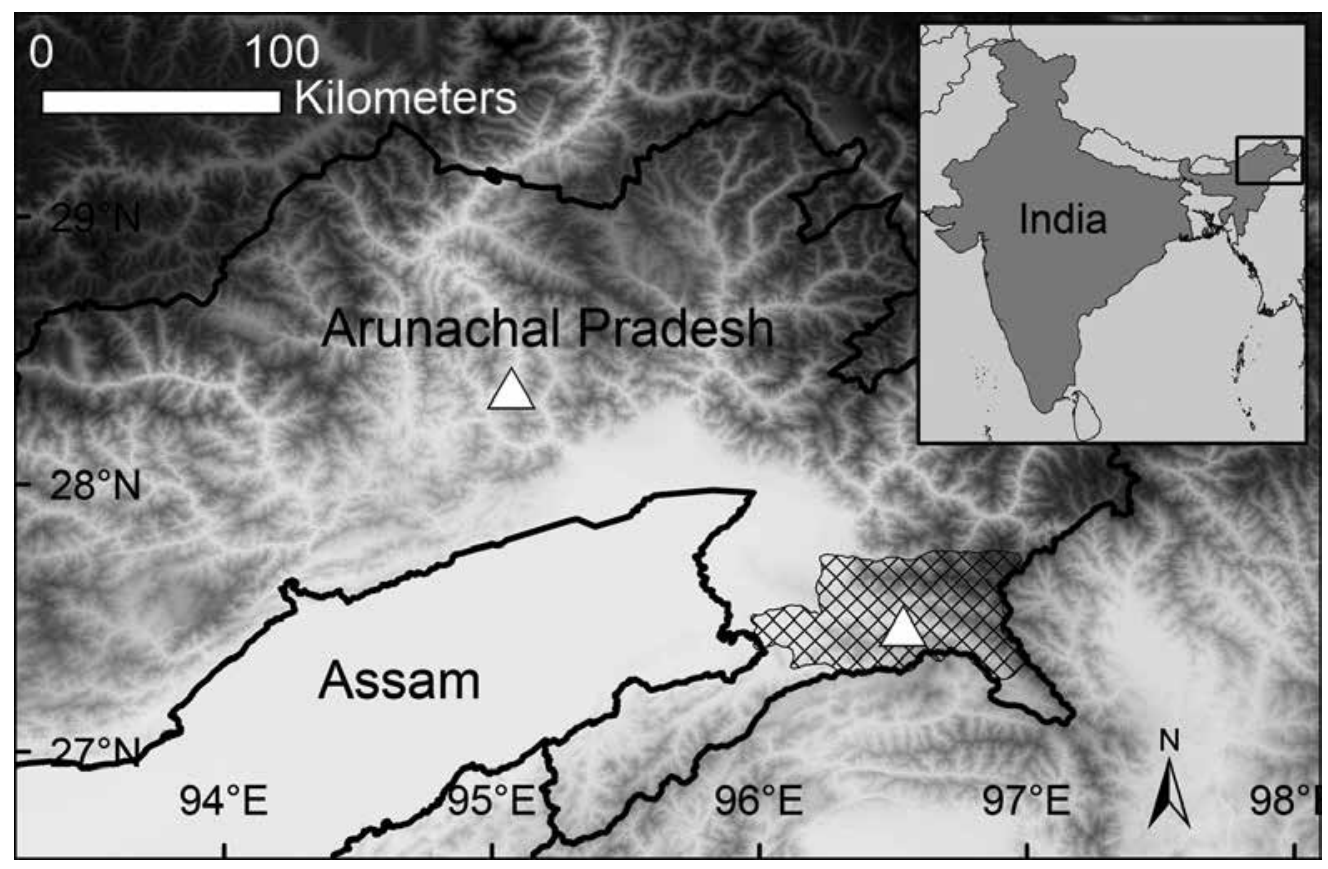

Fig. 3. The location of the two known populations of Begonia oyuniae in Arunachal Pradesh; the shaded area shows the boundary of the Namdapha National Park.

entire, acute. Staminate flowers: pedicel $0.4-1.2 \mathrm{~cm}$ long, glabrous, tepals 4, white transparent, outer 2 obovate, 7-11 $\times 6 \mathrm{~mm}$ wide, glabrous; inner ones 2 , narrowly obovate, 3-6 $\times 2 \mathrm{~mm}$, apex rounded; androecium asymmetric, stamens c. 12 arranged in two rows; inner row anthers c. $2 \mathrm{~mm}$ long, filaments c. $1 \mathrm{~mm}$ long; outer row anthers c. $1 \mathrm{~mm}$ long, filaments c. $1 \mathrm{~mm}$; anthers oblong, c. $1 \mathrm{~mm}$ long, connective not extended apically, obtuse to truncate, dehiscence through unilaterally positioned pores. Pistillate flowers: pedicel $0.4-0.6 \mathrm{~cm}$ long, glabrous or minute glandular hairy when young, glabrous when mature; ovary pale green, glabrous, 2-locular, two placental lamellae per locule, locular part excluding wings ellipsoid, $6 \times 3 \mathrm{~mm}$, 3-winged, wings unequal, longest wing $9 \times 5 \mathrm{~mm}$, ovate, smallest wing $2 \mathrm{~mm}$, elliptic, margins of wings entire, larger wing slightly wrinkled (Taram 301) or slightly verruculose (Krishna 159649); tepals 5-6, elliptic-obovate, subequal, 6-9 × 3-6 mm, white, glabrous; styles 2, free, stigmas lunate. Fruit a curved capsule, pale green, wings strongly unequal, lateral wings ending at the middle of the capsule, cucullate, c. $5 \times 3 \mathrm{~mm}$; medial wing $1.2 \times$ $1.8 \mathrm{~cm}$, slightly wrinkled or verruculose, irregularly dehiscent. Capsule recurved when mature with the two smaller wings forming a splash cup. Seeds numerous, ellipsoid to oblate, c. $0.3 \times 0.2 \mathrm{~mm}$.

Distribution and habitat. Begonia oyuniae is endemic to Arunachal Pradesh, found in Namdapha National Park and in Sikem environs. It grows near streams, waterfalls and moist shaded areas in rock crevices in subtropical evergreen forests and near roadsides at an altitude of $180-400 \mathrm{~m}$. 
Phenology. Flowering and fruiting from April-September.

Etymology. Named after the mother of the first author, Mrs Oyun Taram for her untiring support.

Provisional IUCN conservation assessment. The species is quite common in Sikem, with c. 1000 individuals noted at two locations. The area is private land, not a designated protected area, but no ongoing degradation of habitat was observed. The fact the species can be found in roadside habitats indicates it has the ability to colonise new areas and tolerate some degree of habitat change. One small population was observed at the Namdapha National Park, but it would seem likely other populations will exist in the nearly $2000 \mathrm{~km}^{2}$ protected area. Based on the observations that there is some tolerance of secondary habitats, no ongoing degradation of the current locations, and the likelihood of further populations in Namdapha, we consider a provisional IUCN assessment of Least Concern to be appropriate, based on our current knowledge (IUCN Standards and Petitions Subcommittee, 2017).

Additional specimen examined. INDIA: Arunachal Pradesh: Changlang, Namdapha National Park, on wet granite rocks near to streams, c. 300 m, 5 Aug 2018, Krishna 159649 (CAL, MH).

Notes. This species is likely allied to the type of Begonia sect. Monophyllon due to the shared asymmetric androecium. The only other species in the section, Begonia paleacea, could well be a synonym of the widespread B. integrifolia Dalzell. There are some differences between the collections of Begonia oyuniae from the two localities, with the larger fruit wing being slightly verruculose vs slightly wrinkled, the stipules being minute vs larger, and the number of leaves being 1 or variable 1-3 in the Namdapha National Park and Sikem populations, which are approximately $170 \mathrm{~km}$ apart, respectively. We view these as acceptable variation within the species and not currently worth accepting at a sub-specific rank until further exploration in the remote forests between the populations has been carried out. Collections from these areas may well blur the boundaries between the known populations.

ACKNOWLEDGMENTS. MT \& DB are thankful to Mr Ojar Taku, Gemin Taku, Vijay Taram, Bosong Taram and Olom Tosung for their support in the field. They also extend their sincere gratitude towards their teachers, parents and friends for extending help, cooperation and logistics. NK, AKP \& AA are grateful to the State Forest Department of Arunachal Pradesh for granting permission to conduct field visits; Mr Jaisemon Simon (Department of Botany St. Xavier's College Aluva, Kerala), and Mr Rajeesh, E. P., (Department of Botany, University of Calicut, Kerala), for their help during the field visit. The University Grants Commission, New Delhi (no. F1-17.1/2017-18/RGNF-2017-18-SC-KER-38388/ (SA-III/ Website), dated 26 July 2017) is gratefully acknowledged for providing financial support. All authors are grateful to the curators and staff of the herbaria ASSAM, BSI, BSHC, CAL, CALI, E, MH, SUK and TBGT for permission to consult herbarium specimens. 


\section{References}

Camfield, R. \& Hughes, M. (2018). A revision and one new species of Begonia L. (Begoniaceae, Cucurbitales) in Northeast India. Eur. J. Taxon 396: 1-116.

Clarke, C.B. (1879). Begoniaceae. In: Hooker, J.D. (ed.) Flora of British India, vol. 2, pp. 636-656. London: L. Reeve.

Doorenbos, J.M., Sosef, M.S \& de Wilde, J.J.F.E. (1998). The sections of Begonia including descriptions, keys and species lists: studies in Begoniaceae VI. Wageningen Agricultural University, Wageningen.

Gu, C., Peng, C.-I \& Turland, N. (2007). Begoniaceae. In: Wu, Z.Y \& Raven, P.H. (eds) Flora of China, vol 13, pp. 153-207. Beijing: Science Press \& St. Louis: Missouri Botanical Garden.

Hughes, M., Moonlight, P.W., Jara, A. \& Pullan, M. (2015-). Begonia Resource Centre. http:// padme.rbge.org.uk/begonia. Accessed 26 Feb. 2019.

IUCN Standards and Petitions Subcommittee (2017). Guidelines for Using the IUCN Red List Categories and Criteria. Version 13. Prepared by the Standards and Petitions Subcommittee.

Moonlight, P.W., Ardi, W.H., Padilla, L.A., Chung, K.-F., Fuller, D., Girmansyah, D., Hollands, R., Mahardika, A., Jara-Muñoz, A., Kiew, R. et al. (2018). Dividing and conquering the fastest growing genus: Towards a natural sectional classification of the mega-diverse genus Begonia (Begoniaceae). Taxon 67: 267-323. 
